\title{
La luz en el horizonte
}

\section{Irene Trouselle}

La luz en el horizonte. La tierra se tiñó de rojo, por tanta sangre derramada de sus hermanos de combate. Los días eran como una pesadilla, apenas si daba tiempo de enterrar a los soldados que morían a su alrededor. A Filemón le parecía oír los sollozos de María, su esposa, cuando él le dijo que se uniría a la causa revolucionaria junto con Miguel, el hermano menor. Ella le rogaba que no se fuera, que pensar a en sus hijos. Él contestó "por mis hijos es por lo que tengo que ir, para que ellos tengan una mejor vida, mujer".

Filemón y Miguel dejaron a sus padres; asimismo, Filemón dejaba a su mujer y a sus tres hijos, dos niñas y un varón. Mientras Miguel dejaba a su esposa Azucena, quien estaba esperando un bebé, al cuidado de los padres de ella, en el pueblo de Santa Catarina.

El tiempo transcurrió y al parecer la lucha llegaba a su fin. En Filemón y su hermano surgía la esperanza de volver a ver a sus seres queridos.

Filemón se sintió agradecido al pensar que la vida ofrecida por sus amigos y compañeros en la lucha por la Revolución, no había sido en vano. Por fin cada mexicano tendría un pedacito de tierra para trabajarla y poderle dar de comer a su familia, sin tener que pedirle al amo que le matara el hambre con las pocas migajas que le daba, y poder así vivir una vida más digna.

Tanto Filemón como Miguel sabían que la Revolución era cuestión de tiempo; el pueblo estaba inconforme, sufría hambre y maltrato por parte de los de los hacendados. Los amos se hacían cada vez más ricos con la explotación de sus peones; esa fue la razón principal por la que los dos hermanos se habían unido a la causa revolucionaria.

Filemón pensaba en su querido Santa Catarina. Ese pueblito a las faldas del Cerro El Temeroso, y en aquella iglesia donde la gente se reunía todos los domingos por la mañana para ir a misa y después ir a dar una vuelta en la pintoresca plaza del pueblo. La voz de Miguel lo hizo volver a la realidad; era hora de irse al frente de guerra.

Parecía que la batalla llevaba horas y horas; algunos de los enemigos se rendían y otros huían. Finalmente, las cosas se calmaron, encerraron a los prisioneros y atendieron a los heridos. Miguel buscaba a Filemón frenéticamente; en la batalla se habían separado. Miguel preguntaba a los compañeros si no habían visto a Filemón, a lo que uno de ellos le dijo que la última vez que lo vio fue junto al arroyo. Miguel corrió como desesperado buscándolo, gritando su nombre; tenía que encontrar a su hermano. Habían librado muchas 
batallas contra los pelones, y esta última no sería la excepción. Recordó que, de niños, Filemón siempre fue muy buen hermano; defendía a Miguel de los grandulones y fue también quien lo había enseñado a montar a caballo.

Repentinamente, Miguel encuentra a Filemón “¡No! ¡No! ¡No!”, gritó Miguel. Era Filemón, estaba herido. Su cuerpo estaba tibio, aún respiraba, muy lentamente, pero respiraba. Rápidamente buscó con qué curarlo y se decía a sí, "Dios mío jes mi hermano, no puede morirse!, jno!” Al fin trató de calmarse, lo subió a una carreta y lo llevó al pueblo más cercano, donde el doctor revisó a Filemón.

Miguel esperaba con ansia al doctor, que se acerca y bajando la cabeza le dice, "anda, ve a su lado, no le queda ya mucho tiempo, no le pude sacar la bala y la otra que lo atravesó hizo que perdiera mucha sangre". Le dio una palmada suave en el hombro al mismo tiempo que le señalaba la puerta.

El herido yacía en la cama pálido, casi tan blanco como la sábana; se miraba tan frágil, tan débil. No era ni la sombra de su hermano Filemón, un hombre lleno de energía, fuerte y sano. Miguel tuvo que contener las lágrimas, ya que los hombres no podían ni debían llorar; pero este era su hermano y el dolor que sentía era muy grande. ¿Qué le iba a decir a los viejos, a su cuñada, a sus sobrinos? En ese instante, escucha un murmullo de los labios de Filemón que le dicen "¡hermano!” Miguel se le acerca para escuchar mejor, y Filemón le dice "cuida de mis hijos, diles que los amo con toda mi alma y que siempre voy a estar con ellos, y a mi María dile que no llore, que esto fue necesario por nuestros hijos. Y a los viejos diles que sean fuertes. Hermano, lo vas a hacer, ¿verdad?" 